\title{
Carbon Status in Major Fruit Orchard Soils of Parbhani District of Maharashtra, India
}

\author{
S. P. Zade*, S. L. Bhosale and P. H. Gourkhede \\ Department of Soil Science and Agricultural Chemistry, \\ Vasantrao Naik Marathwada Krishi Vidyapeeth, Parbhani 431402 (M.S.) India \\ *Corresponding author
}

\section{Keywords}

Soil organic carbon (SOC)

Soil inorganic carbon (SIC) global carbon cycle(GCC).

\section{Article Info}

Accepted: 15 February 2020 Available Online: 10 March 2020

\section{A B S T R A C T}

Soil organic carbon (SOC) and Soil inorganic carbon (SIC) are important as it determine ecosystem and agro-ecosystem functions influencing soil structure, soil fertility, water holding capacity, cation exchange capacity and other soil characteristics. It is also of global importance because of its role in the global carbon cycle(GCC). The understanding of soil carbon in terms of its amount and quality is essential to sustain the quality and productivity of soils. With this view an attempt was made to assess the carbon storage under diverse horticultural cropping systems in Parbhani district of Maharashtra. Twelve major fruit orchard soil samples from Parbhani district of Marathwada region at a depth of $0-30 \mathrm{~cm}$ and $30-60 \mathrm{~cm}$ were collected for investigation. The results emerged out indicated that soil organic carbon (SOC) content of orchards soil at $0-30 \mathrm{~cm}$ depth ranged from 21.60 to $25.86 \mathrm{Mg} \mathrm{ha}^{-1}$ and at $30-60 \mathrm{~cm}$ depth it was ranged from 18.54 to $23.13 \mathrm{Mg} \mathrm{ha}^{-1}$. It decreased with the increase in depth. At both the depths, highest SOC recorded in mango orchard soils followed by orange, pomegranate orchards soil. At both the depths, highest soil inorganic carbon (SOI) recorded under mango followed by pomegranate orchard soil sample. The subsurface soils $(30-60 \mathrm{~cm})$ showed higher content inorganic carbon than surface soil $(0-30 \mathrm{~cm})$ which exhibited an increasing trend with increase in depth. The SOC was positively correlated with total organic carbon $\left(\mathrm{r}=0.886^{* *}\right.$ and $\mathrm{r}=0.917 * *)$ at $0-30 \mathrm{~cm}$ and $30-60 \mathrm{~cm}$ depth of soil respectively. The SIC was positively correlated with total organic carbon $\left(\mathrm{r}=0.961^{* *}\right.$ and $\left.\mathrm{r}=0.954^{* *}\right)$ at $0-30 \mathrm{~cm}$ and $30-60 \mathrm{~cm}$ depth of soil respectively. The SIC in soils of semiarid climate is one of the major reservoir of carbon near the surface environment, have a potential in mitigating the effects of global climate change by sequestering the atmosphere carbon in the form of SIC (Pedogenic Carbonate).

\section{Introduction}

Carbon sequestration is the long term storage of carbon dioxide or other forms of carbon in oceans, soils, vegetation (especially forests), and geologic formations to either mitigate or defer global warming. It is the net transfer of atmospheric $\mathrm{CO}_{2}$ into long-lived $\mathrm{C}$ pools. These pools can be extant biomass (e.g. trees), long-term biomass products (e.g. lumber), living biomass in soils (e.g.perennial roots and micro-organisms), or recalcitrant organic and inorganic $\mathrm{C}$ in soils and deeper sub-surface environments (West and Post, 2002).

The primary way that carbon is stored in the soil is as soil organic matter. Soil organic matter is a complex mixture of carbon compounds, consisting of decomposing plant 
and animal tissue, microbes (protozoa, nematodes, fungi, and bacteria), and humus carbon associated with soil minerals. Another way by which carbon get stored in soils under semiarid climatic conditions is through pedogenic $\mathrm{CaCO}_{3}$ formation.

Patil and Kumar (2017) reported that, Carbon sequestration in the agriculture sector refers to the capacity of agriculture, horticulture and forests to remove carbon dioxide from the atmosphere. Carbon dioxide is absorbed by trees, plants and crops through photosynthesis and stored as carbon in biomass in tree trunks, branches, foliage and roots and soils. Forests and stable grasslands are referred to as carbon sinks because they can store large amounts of carbon in their vegetation and root systems for long periods of time. Soils are the largest terrestrial sink for carbon on the planet. The ability of agriculture lands to store or sequester carbon depends on several factors, including climate, soil type, type of crop or vegetation cover and management practices. The amount of carbon stored in soil organic matter is influenced by the addition of carbon from dead plant material and carbon losses from respiration, the decomposition process and both natural and human disturbance of the soil. By employing farming practices that involve minimal disturbance of the soil and encourage carbon sequestration, farmers may be able to slow or even reverse the loss of carbon from their fields.

The fruits based system is a self sustainable system where solar energy can be harvested at different heights, soil resources can be efficiently used and cropping intensity is increased. The system consists of three main components viz., main crop, filler crop and inter crops which occupy three different tiers in space of the production system. Carbon in trees can be stored in trunks, branches, leaves, flowers, fruits and roots, exposure of tropical and subtropical fruit trees (avocado, banana, mangosteen, citrus and mango) to elevated concentration of $\mathrm{CO}_{2}$ significantly increased the rate of photosynthesis and consequently an increase in tree biomass. Photosynthesis in mangosteen increased by 40 to $60 \%$ when exposed to $800 \mathrm{ppm}$ for one year compared to when exposed to ambient $\mathrm{CO}_{2}$ concentration. Prolific flowering and fruiting abilities of trees increase carbon removal from atmosphere and store substantial amount of carbon as cellulose. Fruit orchards can positively contribute to a sustainable development under climate change scenario in the tropics considering the current expansion of agriculture and high level of poverty which continue to shrink forest resources (Patil and Kumar, 2017).

Bhavya et al.,(2017) reported that, growing of perennial horticultural crops is one of the strategies to improve soil conditions which would result in enhancing soil attributes and contributing to the good soil health and helps to sequester more organic carbon and carbon dioxide in soil as compared to annual crops. Although the benefits of perennial horticultural crops on soil in improving its chemical properties have been well known. But the potential of fruit trees to sequester carbon and carbon storage or balance in the soil of semi-arid tropics (SAT) of Marathwada region of Maharashtra remains unexploited. The present study is an attempt to assess the carbon storage under diverse horticultural cropping systems in Parbhani district of Maharashtra.

\section{Materials and Methods}

Parbhani is situated at a height of about 423.46 meters above the mean sea level within the Godavari drainage basin in the central part of India between $76^{\circ}, 46^{\prime}$ East longitude and $19^{\circ}, 16^{\prime}$ North longitude. The area falls under semi arid tropics. The average annual precipitation of the last 35 years was 
$960.7 \mathrm{~mm}$. July is wetted month of the year covering about 27.4 per cent of annual rainfall. The precipitation is assured for kharif season and for sowing Rabi crops.

The soils under study area are black, formed from the weathering of "Deccan trap" rock (basalt) which is rich in iron, copper and magnesium. The experimental soil is characterized by black colour dominated by Montmorillonite clay with high coefficient of expansion and shrinkage in summer which leads to deep cracking.

Twelve major fruit orchards soil samples viz., Custard apple, Papaya, Orange, sweet orange , Banana, Guava, Lemon, Mango, Aonla, Pomegranate, Tamarind and Sapota from Parbhani district of Marathwada region selected investigation. (Plate 1.). Twenty four representative GPS based soil samples were collected from the selected orchards from 0 $30 \mathrm{~cm}$ and 30-60 $\mathrm{cm}$ depth in peripheral area of each tree orchards depending upon the area for estimation physico-chemical and biological properties in order to know the soil nutrient status of the orchards soil.

Total organic carbon was determined by using TOC analyser on TOC SHIMADZU TOC analyser $5000 \mathrm{~A}$ as described by (Tiessen $\mathrm{H}$. And J.O. Moir, 1993). Soil inorganic carbon was determined by heated dichromate method as described by (Technical manual USETA, 2001). Water soluble carbon was extracted by method given by Mc Gill et al. (1986). Ten gram soil was taken in centrifuge tube and shaken on rotator shaker with $30 \mathrm{ml}$ of distilled water for an hour followed by centrifugation for 60 minutes at $5000 \mathrm{rpm}$ to clear the supernatant filter through whatman no. 1 filter paper. $10 \mathrm{ml}$ supernatant aliquot was taken followed by $5 \mathrm{ml}$ of $0.1 \mathrm{~N} \mathrm{~K}_{2} \mathrm{Cr}_{2} \mathrm{O}_{7}$ subsequently added $10 \mathrm{ml}$ of concentrated sulphuric acid and $5 \mathrm{ml}$ of $88 \% \mathrm{H}_{3} \mathrm{PO}_{4}$ orthophosphoric acid and kept on water bath for 1 hour or digested at $150^{\circ} \mathrm{C}$ for 30 minutes. Samples were titrated against $0.01 \mathrm{~N}$ ferrous ammonium sulphate (FAS) using $1 \mathrm{ml}$ of diphenylamine indicator or ferroin indicator. Colour changes from green to bluish green and finally dark grayish red. Oxidizable organic carbon was determined by using potassium permanganate method as suggested by (Weil et al., 2003)

\section{Soil carbon pools}

\section{Labile carbon (oxidizable organic carbon) and non labile carbon}

Labile and non labile carbon or oxidizable soil organic carbon content of the soil determined by wet oxidation Walkley and Black method described by (Chan et al., 2001)

\section{Estimation of carbon content}

Calculation of soil carbon content of experimental site requires determination of soil organic carbon (OC) concentration, bulk density (BD), and soil depth, which all vary in space and have different measurement errors associated.

The carbon content was calculated by following formula given by Subhash Babu et al., (2018).

Soil Organic Carbon Content $\left(\mathrm{Mg} \mathrm{ha}^{-1}\right)$

$=$ SOC concentration $\left(\mathrm{g} \mathrm{kg}^{-1}\right) \times$ Bulk density $\left(\mathrm{Mg} \mathrm{m}^{-3}\right) \times$ Depth (m) x10

Soil Inorganic Carbon Content $\left(\mathrm{Mg} \mathrm{ha}^{-1}\right)$ $=$ SIC concentration $\left(\mathrm{g} \mathrm{kg}^{-1}\right) \times$ Bulk density $\left(\mathrm{Mg} \mathrm{m}^{-3}\right) \times$ Depth $(\mathrm{m}) \times 10$

\section{Results and Discussion}

In general, the soils under different fruit orchards in Parbhani district of Maharashtra 
are slightly alkaline in nature. The bulk density of soil ranges between 1.23 to 1.33 $\mathrm{Mg} \mathrm{\textrm {m } ^ { - 3 }}$ and increases with depth. The organic carbon content of fruit orchard soils ranged from 5.60 to $7.01 \mathrm{~g} \mathrm{~kg}^{-1}$ with mean value of $6.30 \mathrm{~g} \mathrm{~kg}^{-1}$ at $0-30 \mathrm{~cm}$ depth and at $30-60 \mathrm{~cm}$ depth it was ranged from 4.61 to $6.12 \mathrm{~g} \mathrm{~kg}^{-1}$ with mean value of $5.36 \mathrm{~g} \mathrm{~kg}^{-}$ ${ }^{1}$ (Table 2)

The highest organic carbon content recorded in mango fruit orchard soils followed by pomegranate may be due to the continuous addition of organic matter by continuous falling of leaves in perennial crops like mango and pomegranate orchard leads to accumulate more organic matter to the soil. However, the lowest organic carbon noticed in sapota fruit orchards soils at $0-30 \mathrm{~cm}$ and $30-60 \mathrm{~cm}$ depth. The maximum organic carbon was recorded in surface soil as compared to the subsurface soils due to natural vegetation and addition of organic matter by farmers. It is decreased with an increase in soil depth.

\section{Inorganic carbon}

The results indicate that the inorganic carbon (IC) of fruit orchards soil samples at $0-30 \mathrm{~cm}$ depth ranged from 8.41 to $11.40 \mathrm{~g} \mathrm{~kg}^{-1}$ with mean value of $9.90 \mathrm{~g} \mathrm{~kg}^{-1}$ and at $30-60 \mathrm{~cm}$ depth it was ranged from 8.47 to $11.45 \mathrm{~g} \mathrm{~kg}^{-1}$ with mean value of $9.96 \mathrm{~g} \mathrm{~kg}^{-1}$ (Table 2). At both the depths of $0-30 \mathrm{~cm}$ and $30-60 \mathrm{~cm}$, lowest inorganic carbon recorded in lemon fruit orchard soil sample and highest inorganic carbon recorded in mango fruit orchard soil sample. The subsurface soils (30$60 \mathrm{~cm}$ ) showed higher content inorganic carbon than surface soil $(0-30 \mathrm{~cm})$ which exhibited a increasing trend with increase in depth.

The increase in inorganic carbon could be due to the presence of lithogenic inorganic carbon or secondary carbonates under semi arid climate where the evapotranspiration far exceeds precipitation (Bhatacharya et al., 2001; Lal R. 2002 and Chaudhary et al., 2017).

\section{Total organic carbon}

The total organic carbon content of fruit orchards soils ranged from 14.02 to $18.44 \mathrm{~g}$ $\mathrm{kg}^{-1}$ with mean value of $16.23 \mathrm{~g} \mathrm{~kg}^{-1}$ at $0-30$ $\mathrm{cm}$ depth and at 30-60 $\mathrm{cm}$ depth it was ranged from 13.98 to $18.42 \mathrm{~g} \mathrm{~kg}^{-1}$ with mean value of $16.20 \mathrm{~g} \mathrm{~kg}^{-1}$ (Table 2). The highest total organic carbon content recorded in mango fruit orchards soils followed by pomegranate and orange. However, the lowest total organic carbon content noticed in sapota fruit orchard soils at $0-30 \mathrm{~cm}$ and $30-60 \mathrm{~cm}$ depths. The maximum total organic carbon content was recorded in surface soil as compared to the subsurface soils due to natural vegetation and addition of organic matter by farmers. It is decreased with an increase in soil depth (Dar et al. 2017).

According to Wang et al., (2009) who reported that increase in TOC was more in surface as compared to the sub-surface soil, which indicated higher accumulation of organic carbon due to application of FYM was confined to surface soil. Build up of higher amount TOC in surface soil over subsurface soil is due to organic matter or also may be due to accumulation of organic matter from root biomass and root exudates results in such variation in soil depths (Rudraapa et al., 2006).

\section{Water soluble carbon}

Results noted in Table 2 indicated that water soluble carbon content of fruit orchard soils ranged from 19.90 to $31.30 \mathrm{mg} \mathrm{kg}^{-1}$ with mean value of $25.60 \mathrm{mg} \mathrm{kg}^{-1}$ at $0-30 \mathrm{~cm}$ depth and at $30-60 \mathrm{~cm}$ depth it was ranged from 15.22 to $27.32 \mathrm{mg} \mathrm{kg}^{-1}$ with mean value of 
$21.27 \mathrm{mg} \mathrm{kg}^{-1}$. The highest water soluble carbon recorded in pomegranate fruit orchards soils followed by mango and orange. However, the lowest water soluble carbon noticed in lemon fruit crop soil sample at 0-30 $\mathrm{cm}$ and 30-60 $\mathrm{cm}$ depth.

The maximum water soluble carbon was recorded in surface soil as compared to the subsurface soils. It may be due to addition of plant residues and microbial activity. The increase in water soluble carbon content with application of nitrogenous fertilizers could be as a result of priming effect of applied inorganic nitrogen on fresh organic material in the soil, which stimulates the microbial activity helping in decomposition of soil organic matter with rapid release of water soluble carbon fraction (Brar et al. 2013). Similarly Kumari et al. (2011) also reported that FYM sustain higher amount of water soluble carbon, where as increasing graded dose of chemical fertilizers increased their content in soil. The decrease of water soluble carbon concentration in deep soil horizons may attribute to adsorptive interaction of water soluble carbon with reactive surface of the mineral matrix (Kalbitz et al. 2000).

\section{Soil organic carbon pool}

\section{Labile carbon (oxidizable organic carbon)}

The perusal of the data presented in Table 2 . showed that the labile carbon content of fruit orchards soils at $0-30 \mathrm{~cm}$ depth ranged from 253 to $381 \mathrm{mg} \mathrm{kg}^{-1}$ with mean value of 317 $\mathrm{mg} \mathrm{kg}^{-1}$ and the ranged from 191 to $324 \mathrm{mg}$ $\mathrm{kg}^{-1}$ with mean value of $287.5 \mathrm{mg} \mathrm{kg}^{-1}$ at 30 $60 \mathrm{~cm}$ depth. The highest labile carbon content was recorded in mango fruit orchard soils at both the depths of soil and lowest labile carbon content was recorded in sweet orange and aonla fruits orchard soil at 0-30 $\mathrm{cm}$ and 30-60 $\mathrm{cm}$ soil depths respectively. The depth wise distribution of labile carbon showed decreasing trend with increasing depth. The higher value of labile carbon content in surface soil layer might be due to more addition of crop residue and organic manure and it decreased with the depth.

\section{Non labile carbon}

The results showed that the non labile carbon content of fruit orchards soils ranged from 348 to $598 \mathrm{mg} \mathrm{kg}^{-1}$ with mean value of 473 $\mathrm{mg} \mathrm{kg}^{-1}$ at $0-30 \mathrm{~cm}$ depth and at $30-60 \mathrm{~cm}$ depth it was ranged from 467 to $685 \mathrm{mg} \mathrm{kg}^{-1}$ with mean value of $576 \mathrm{mg} \mathrm{kg}^{-1}$ (Table 2). The highest content of non labile carbon content recorded in lemon fruit orchard soils followed by aonla and the lowest value of non labile carbon content noticed in pomegranate fruit orchard soil at $0-30 \mathrm{~cm}$ and $30-60 \mathrm{~cm}$ depth.

From the data it was observed that the non labile carbon content higher in subsurface soils than surface layer soils. With depth increment passive pool carbon content was increased due to more physical, chemical and biochemical stabilization of organic carbon in lower depths of soil. Increase in passive pool carbon with depth due to the increase in silt + clay content with depth increment. In subsoil horizons SOC was preferentially associated with clay fraction. However, direct inputs from roots can be a pathway for SOC to enter lower horizons. Sorption to the mineral phase in subsoil might be more effective than top soils because mineral surface were not yet saturated with organic matter with increase in depth, silt and clay content also increased which might have played an important role in conserving SOC at passive pool particularly under organic manure and inorganic fertilizers (Datta et al. 2015).

\section{Soil organic carbon content (SOCC)}

The data presented in Table 3 showed that the SOCC of fruit orchards soil samples at 0-30 
cm depth ranged from 21.60 to $25.86 \mathrm{Mg} \mathrm{ha}^{-1}$ with mean value of $23.73 \mathrm{Mg} \mathrm{ha}^{-1}$ and at 30$60 \mathrm{~cm}$ depth it was ranged from 18.54 to23.13 $\mathrm{Mg} \mathrm{ha}^{-1}$ with mean value of $20.83 \mathrm{Mg} \mathrm{ha}^{-1}$. At both the depths of $0-30 \mathrm{~cm}$ and $30-60 \mathrm{~cm}$, highest SOCC recorded in mango orchard soils followed by orange. However, the lowest SOCC recorded in aonla fruit orchard soils. Pichhode et al.,(2017) observed maximum carbon sequestration capability was by Mangifera indica (2.015t) among different tree species. The surface soils $(0-30 \mathrm{~cm})$ showed higher content SOCC than subsurface soil $(30-60 \mathrm{~cm})$ which exhibited a decreasing trend with increase in depth, which might be due to higher organic matter at surface soils (Bhat et al. 2017).

\section{Soil inorganic carbon content (SICC)}

The data showed that the SICC of fruit orchards soil samples at 0-30 $\mathrm{cm}$ depth ranged from 33.30 to $42.16 \mathrm{Mg} \mathrm{ha}^{-1}$ with mean value of $37.73 \mathrm{Mg} \mathrm{ha}^{-1}$ and at $30-60 \mathrm{~cm}$ depth it was ranged from 34.30 to $43.28 \mathrm{Mg} \mathrm{ha}^{-1}$ with mean value of $38.79 \mathrm{Mg} \mathrm{ha}^{-1}$ (Table 3). At both the depths of $0-30 \mathrm{~cm}$ and $30-60 \mathrm{~cm}$, lowest SICC recorded in lemon fruit orchard soil sample and highest SICC recorded in mango fruit orchard soil sample followed by pomegranate. The subsurface soils $(30-60 \mathrm{~cm})$ showed higher content SICC than surface soil $(0-30 \mathrm{~cm})$ which exhibited an increasing trend with increase in depth.

Table.1 Details of selected fruit orchards from Parbhani district of Marathwada region, Maharashtra

\begin{tabular}{|c|c|c|c|c|c|c|c|}
\hline $\begin{array}{l}\text { Sr } \\
\text { No. }\end{array}$ & $\begin{array}{l}\text { Name of } \\
\text { Orchard }\end{array}$ & Name of Farmer & $\begin{array}{c}\text { Area of } \\
\text { Orchard } \\
\text { (Acre) }\end{array}$ & $\begin{array}{c}\text { Age of } \\
\text { Orchard } \\
\text { (Years) }\end{array}$ & GPS Location & Taluka & Village \\
\hline 1 & $\begin{array}{l}\text { Custard } \\
\text { apple }\end{array}$ & $\begin{array}{l}\text { Mr. Mukundrao } \\
\text { Rambhau Pawar }\end{array}$ & 2.5 & 19 & $\begin{array}{l}19^{0} 22.901 " \\
76^{0} 29.411^{\prime \prime}\end{array}$ & Selu & Zodgaon \\
\hline 2 & Papaya & $\begin{array}{c}\text { Mr. Sachin } \\
\text { Rameshrao } \\
\text { Pathare }\end{array}$ & 2.5 & 1 & $\begin{array}{l}19^{0} 21.160^{\prime \prime} \\
76^{0} 36.398^{\prime \prime}\end{array}$ & Parbhani & $\begin{array}{c}\text { Tad } \\
\text { Borgaon }\end{array}$ \\
\hline 3 & Orange & $\begin{array}{c}\text { Mr. Anurath } \\
\text { Banjirao Nirval }\end{array}$ & 9 & 6 & $\begin{array}{l}19^{0} 20.604^{\prime \prime} \\
76^{0} 31.599^{\prime \prime}\end{array}$ & Manwat & Rudi \\
\hline 4 & $\begin{array}{l}\text { sweet } \\
\text { orange }\end{array}$ & Mr. Sanjay Thore & 2 & 11 & $\begin{array}{l}19^{0} 17.444^{\prime \prime} \\
76^{0} 25.588^{\prime \prime}\end{array}$ & Pathri & Mudgal \\
\hline 5 & Banana & Mr. Abdul Majid & 1.5 & 3 & $\begin{array}{l}19^{0} 17.086^{\prime \prime} \\
76^{0} 25.818^{\prime \prime}\end{array}$ & Pathri & Devnandra \\
\hline 6 & Guava & $\begin{array}{l}\text { Mr. Bhimrao } \\
\text { Linbaji Jadhav }\end{array}$ & 2 & 3 & $\begin{array}{l}19^{0} 23.599^{\prime \prime} \\
76^{0} 46.135^{\prime \prime}\end{array}$ & Parbhani & Khanapur \\
\hline 7 & Lemon & $\begin{array}{l}\text { Mr. Kailas } \\
\text { Mantri }\end{array}$ & 5 & 25 & $\begin{array}{l}19^{0} 24.980^{\prime \prime} \\
76^{0} 45.934^{\prime \prime}\end{array}$ & Parbhani & Zari \\
\hline 8 & Mango & $\begin{array}{c}\text { Mr. Laxman } \\
\text { Baburao } \\
\text { Warkdkar }\end{array}$ & 1 & 15 & $\begin{array}{l}19^{0} 28.740^{\prime \prime} \\
76^{0} 44.539^{\prime \prime}\end{array}$ & Jintur & Bori \\
\hline 9 & Aonla & $\begin{array}{l}\text { Mr. Sureshrao } \\
\text { Deshmukh }\end{array}$ & 5 & 25 & $\begin{array}{l}19^{\circ} 18.329^{\prime \prime} \\
76^{0} 44.783^{\prime \prime}\end{array}$ & Parbhani & Khanapur \\
\hline 10 & Pomegranate & $\begin{array}{l}\text { Mr. Sadashiv } \\
\text { Dattatray More }\end{array}$ & 4.5 & 7 & $\begin{array}{l}19^{0} 26.365^{\prime \prime} \\
76^{0} 29.198^{\prime \prime}\end{array}$ & Parbhani & $\begin{array}{c}\text { Tad } \\
\text { Borgaon }\end{array}$ \\
\hline 11 & Tamarind & $\begin{array}{c}\text { Mr. Anurath } \\
\text { Bajirao Nirwal }\end{array}$ & 4 & 13 & $\begin{array}{l}19^{0} 20.604^{\prime \prime} \\
76^{0} 31.599^{\prime \prime}\end{array}$ & Manwat & Rudi \\
\hline 12 & Sapota & $\begin{array}{l}\text { Mr. Sultan } \\
\text { Pathan }\end{array}$ & 5 & 10 & $\begin{array}{l}19^{0} 24.664 " \\
76^{0} 42.542^{\prime \prime}\end{array}$ & Sonpeth & Sirsi \\
\hline
\end{tabular}


Table.2 Carbon fractions status of major fruit orchards growing soils of Parbhani district of Marathwada region

\begin{tabular}{|c|c|c|c|c|c|c|}
\hline $\begin{array}{c}\text { Depth } \\
\text { (cm) }\end{array}$ & $\begin{array}{l}\text { Organic } \\
\text { Carbon } \\
\left(\mathrm{g} \mathrm{kg}^{-1}\right)\end{array}$ & $\begin{array}{l}\text { Inorganic } \\
\text { Carbon } \\
\left(\mathrm{g} \mathrm{kg}^{-1}\right)\end{array}$ & $\begin{array}{c}\text { Total } \\
\text { Carbon } \\
\left(\mathrm{g} \mathrm{kg}^{-1}\right)\end{array}$ & Water $\begin{array}{c}\text { Soluble Carbon } \\
\left(\mathrm{mg} \mathrm{kg}^{-1}\right)\end{array}$ & $\begin{array}{c}\text { Labile } \\
\text { Carbon } \\
\left(\mathrm{mg} \mathrm{kg}^{-1}\right)\end{array}$ & $\begin{array}{l}\text { Non Labile } \\
\text { Carbon } \\
\left(\mathrm{mg} \mathrm{kg}^{-1}\right)\end{array}$ \\
\hline \multicolumn{7}{|c|}{ Custard apple (Selu) } \\
\hline $0-30$ & 6.02 & 8.92 & 15.03 & 20.45 & 265 & 378 \\
\hline $30-60$ & 5.07 & 9.05 & 14.99 & 17.53 & 209 & 494 \\
\hline W.M & 5.54 & 8.98 & 15.01 & 18.99 & 237 & 436 \\
\hline \multicolumn{7}{|c|}{ Papaya (Parbhani) } \\
\hline 0-30 & 6.30 & 9.29 & 15.68 & 25.18 & 285 & 445 \\
\hline $30-60$ & 5.34 & 9.35 & 15.65 & 20.37 & 228 & 568 \\
\hline W.M & 5.82 & 9.32 & 15.66 & 22.77 & 256.5 & 506.5 \\
\hline \multicolumn{7}{|c|}{ Orange (Manwat) } \\
\hline $\mathbf{0 - 3 0}$ & 6.59 & 10.35 & 17.30 & 29.68 & 315 & 496 \\
\hline $30-60$ & 5.64 & 10.40 & 17.27 & 24.43 & 257 & 609 \\
\hline W.M & 6.11 & 10.37 & 17.28 & 27.05 & 286 & 552.5 \\
\hline \multicolumn{7}{|c|}{ Sweet orange (Pathri) } \\
\hline $0-30$ & 6.45 & 9.41 & 15.90 & 24.89 & 253 & 370 \\
\hline $30-60$ & 5.48 & 9.46 & 15.89 & 19.48 & 198 & 490 \\
\hline W.M & 5.96 & 9.43 & 15.89 & 22.18 & 225.5 & 430 \\
\hline \multicolumn{7}{|c|}{ Banana (Pathri) } \\
\hline $0-30$ & 6.57 & 9.92 & 16.55 & 26.35 & 292 & 417 \\
\hline $30-60$ & 5.61 & 9.95 & 16.52 & 21.83 & 234 & 532 \\
\hline W.M & 6.09 & 9.93 & 16.53 & 24.09 & 263 & 474.5 \\
\hline \multicolumn{7}{|c|}{ Guava (Parbhani) } \\
\hline $0-30$ & 5.88 & 8.92 & 14.69 & 20.79 & 286 & 366 \\
\hline $30-60$ & 4.91 & 8.96 & 14.65 & 17.68 & 225 & 491 \\
\hline W.M & 5.39 & 8.94 & 14.67 & 19.23 & 255.5 & 428.5 \\
\hline \multicolumn{7}{|c|}{ Lemon (Parbhani) } \\
\hline $0-30$ & 5.61 & 8.41 & 14.06 & 19.90 & 273 & 598 \\
\hline $30-60$ & 4.63 & 8.47 & 14.03 & 15.22 & 214 & 685 \\
\hline W.M & 5.12 & 8.44 & 14.04 & 17.56 & 243.5 & 641.5 \\
\hline \multicolumn{7}{|c|}{ Mango (Jintur) } \\
\hline 0-30 & 7.01 & 11.40 & 18.44 & 31.29 & 381 & 430 \\
\hline $30-60$ & 6.12 & 11.45 & 18.42 & 27.29 & 324 & 555 \\
\hline W.M & 6.56 & 11.42 & 18.43 & 29.29 & 352.5 & 492.5 \\
\hline \multicolumn{7}{|c|}{ Aonla (Parbhani) } \\
\hline 0-30 & 5.67 & 9.24 & 15.05 & 23.53 & 254 & 582 \\
\hline $30-60$ & 4.72 & 9.27 & 15.03 & 19.13 & 191 & 671 \\
\hline W.M & 5.19 & 9.25 & 15.04 & 21.33 & 222.5 & 626.5 \\
\hline \multicolumn{7}{|c|}{ Pomegranate (Parbhani) } \\
\hline 0-30 & 6.69 & 11.15 & 17.81 & 31.30 & 273 & 348 \\
\hline $30-60$ & 5.74 & 11.19 & 17.78 & 27.32 & 209 & 467 \\
\hline W.M & 6.21 & 11.17 & 17.79 & 29.31 & 241 & 407.5 \\
\hline \multicolumn{7}{|c|}{ Tamarind (Manwat) } \\
\hline 0-30 & 5.62 & 8.96 & 14.70 & 19.92 & 269 & 355 \\
\hline $30-60$ & 4.66 & 9.02 & 14.68 & 15.29 & 214 & 481 \\
\hline W.M & 5.14 & 8.99 & 14.69 & 17.60 & 241.5 & 418 \\
\hline \multicolumn{7}{|c|}{ Sapota (Sonpeth) } \\
\hline $0-30$ & 5.60 & 9.02 & 14.02 & 20.03 & 264 & 428 \\
\hline $30-60$ & 4.61 & 9.07 & 13.98 & 16.93 & 204 & 545 \\
\hline W.M & 5.10 & 9.04 & 14.00 & 18.48 & 234 & 486.5 \\
\hline
\end{tabular}


Table 3. Soil organic carbon content (SOCC) and soil inorganic carbon content (SICC) of major fruit orchards growing soils of Parbhani district of Marathwada region

\begin{tabular}{|c|c|c|}
\hline Depth (cm) & $\begin{array}{c}\text { SOC Content } \\
\left(\mathrm{Mg} \mathrm{ha}^{-1}\right)\end{array}$ & $\begin{array}{c}\text { SIC Content } \\
\left(\mathrm{Mg} \mathrm{ha}^{-1}\right)\end{array}$ \\
\hline \multicolumn{3}{|c|}{ Custard apple (Selu) } \\
\hline 0-30 & 24.01 & 35.59 \\
\hline $30-60$ & 20.68 & 36.92 \\
\hline W.M & 22.34 & 36.25 \\
\hline \multicolumn{3}{|c|}{ Papaya (Parbhani) } \\
\hline 0-30 & 24.57 & 36.23 \\
\hline $30-60$ & 21.30 & 37.30 \\
\hline W.M & 22.93 & 36.76 \\
\hline \multicolumn{3}{|c|}{ Orange (Manwat) } \\
\hline 0-30 & 25.50 & 40.05 \\
\hline $30-60$ & 22.16 & 40.87 \\
\hline W.M & 23.83 & 40.46 \\
\hline \multicolumn{3}{|c|}{ Sweet orange (Pathri) } \\
\hline 0-30 & 24.76 & 36.13 \\
\hline $30-60$ & 21.37 & 36.89 \\
\hline W.M & 23.06 & 36.51 \\
\hline \multicolumn{3}{|c|}{ Banana (Pathri) } \\
\hline 0-30 & 24.83 & 37.49 \\
\hline $30-60$ & 21.54 & 38.20 \\
\hline W.M & 23.18 & 37.84 \\
\hline \multicolumn{3}{|c|}{ Guava (Parbhani) } \\
\hline 0-30 & 23.10 & 35.05 \\
\hline $30-60$ & 19.73 & 36.01 \\
\hline W.M & 21.41 & 35.53 \\
\hline \multicolumn{3}{|c|}{ Lemon (Parbhani) } \\
\hline 0-30 & 22.21 & 33.30 \\
\hline $30-60$ & 18.75 & 34.30 \\
\hline W.M & 20.48 & 33.80 \\
\hline \multicolumn{3}{|c|}{ Mango (Jintur) } \\
\hline 0-30 & 25.86 & 42.16 \\
\hline $30-60$ & 23.13 & 43.28 \\
\hline W.M & 24.49 & 42.72 \\
\hline \multicolumn{3}{|c|}{ Aonla (Parbhani) } \\
\hline 0-30 & 21.60 & 35.20 \\
\hline $30-60$ & 18.54 & 36.43 \\
\hline W.M & 20.07 & 35.81 \\
\hline \multicolumn{3}{|c|}{ Pomegranate (Parbhani) } \\
\hline 0-30 & 25.28 & 42.14 \\
\hline $30-60$ & 22.04 & 42.96 \\
\hline W.M & 23.66 & 42.55 \\
\hline \multicolumn{3}{|c|}{ Tamarind (Manwat) } \\
\hline 0-30 & 22.25 & 35.48 \\
\hline $30-60$ & 18.87 & 36.53 \\
\hline W.M & 20.56 & 36.00 \\
\hline \multicolumn{3}{|c|}{ Sapota (Sonpeth) } \\
\hline 0-30 & 21.84 & 35.17 \\
\hline $30-60$ & 18.70 & 36.18 \\
\hline W.M & 20.27 & 35.67 \\
\hline
\end{tabular}


Table 4. Correlation coefficient ( $r *$ values) between soil organic carbon content (SOCC) and soil inorganic carbon content (SICC) with total organic carbon (TOC)

\begin{tabular}{|c|c|c|c|}
\hline No. & Parameter Y & Parameter X & "r" value \\
\hline \multicolumn{4}{|c|}{ 0-30 cm depth } \\
\hline 1 & SOCC & TOC & $\mathrm{r}=0.886^{* *}$ \\
\hline 2 & SICC & TOC & $\mathrm{r}=0.961 * *$ \\
\hline \multicolumn{4}{|c|}{$30-60 \mathrm{~cm}$ depth } \\
\hline 5 & SOCC & TOC & $\mathrm{r}=0.917 * *$ \\
\hline 6 & SICC & TOC & $\mathrm{r}=0.954 * *$ \\
\hline
\end{tabular}

SOCC $=$ Soil organic carbon content, $\mathrm{SICC}=$ Soil inorganic carbon content, TOC $=$ Total organic carbon

** Correlation is significant at the $1 \%$ level

The increase in SICC might be due to the interaction of organic acid released during decomposition of organic materials which in turn lead to an increase in inorganic carbon. This $\mathrm{CO}_{2}$ must have combined with the exchangeable calcium through a series of reactions resulting in the formation of $\mathrm{CaCO}_{3}$ leading to significant increase in inorganic carbon content (Singh et al. 2007; Kharche et al. 2013).

Correlation coefficient ( $r *$ values) between soil organic carbon content (SOCC) and soil inorganic carbon content (SICC) with total organic carbon (TOC)

The data presented in Table 4. indicate that the soil organic carbon content (SOCC) were positively correlated with total organic carbon $\left(\mathrm{r}=0.886^{* *}\right.$ and $\left.\mathrm{r}=0.917^{* *}\right)$ at $0-30 \mathrm{~cm}$ and $30-60 \mathrm{~cm}$ depth of soil respectively and soil inorganic carbon content (SICC) were positively correlated with total organic carbon $\left(\mathrm{r}=0.961^{* *}\right.$ and $\left.\mathrm{r}=0.954^{* *}\right)$ at $0-30 \mathrm{~cm}$ and $30-60 \mathrm{~cm}$ depth of soil respectively.

On the basis of foregoing results it was concluded that carbon stock under different fruit orchards soils within the same locality was more in mango orchards soils followed by Pomegranate orchards soils. The highest organic carbon content recorded in mango fruit orchard soils followed by pomegranate due to the continuous addition of organic matter by continuous falling of leaves in perennial crops like mango and pomegranate leads to accumulate more organic matter to the soil. The SOC content under fruit orchards soils decreased with the depth and SIC content increased with depth.

\section{References}

Bhat, Z.A., Akhtar, F.A., Padder, S.A., Ganale, A.Q., Rehman, H.U., Dar, N.A. and Gill, R.K. (2017). Nutrient status of grape orchard soils of jammu and Kashmir, India. Moj Ecology and Environ. Sci. 2(5): 12-19.

Bhattacharyya, T., Pal, D.K., Velayutham, M., Chandran, P and Mandal, C. (2001) Soil organic and inorganic carbon stocks in the management of block cotton soils of Maharastra. Clay Res., 20: 21-29.

Bhavya, V.P, Anil Kumar, S., Shiva Kumar, K.M., Asok Alur and Shivanna, M. (2017). Land use systems to improve carbon sequestration in soils for mitigation of climate change. International Journal of chemical studies., 5 (4): 2019-2021.

Brar, B.S., Singh, K. Dheri, G.S. and Kumar, B. (2013) Carbon sequestration and soil 
carbon pools in rice-wheat cropping system: Effect of long-term use of inorganic fertilizers and organic manure. Soil Tillage Res. 128: 30-36.

Chan, K.Y., Bowman A. and Oates, A. (2001) Oxidizable organic carbon fractions and soil quality changes in an oxicpaleu staff under different pastures leys. Soil Science. 166: 61-67.

Chaudhary, K., Sharma, S. R., Jat, R. and Didal, V.K. (2017) Effect of organic manures and mineral nutrients on quality parameters and economics of sesame (Sesamum indicumL.). J. Pharmacognosy Phytochemistry, 6 (3): 263-265.

Dar, M. A., Rasool, R., Maqbool, M., Wani, J. A., Bhat, M. Y., \& Ramzan, S. (2017). Depth Wise Distribution of Primary Nutrients in Pear Orchard Soils of Kashmir, India. Int. J. Curr. Microbiol. App. Sci, 6 (6): 2526-2539.

Datta, A., Basak, N., Chaudhari, S.K and Shar ma, D.K. (2015) Soil properties and organic carbon distribution under different land uses in reclaimed sodic soils of North-West India. Geoderma Regional. 4: 134-146.

Kalbitz, K., Solinger, S., Park, J.H., Michalzik, B and Matzner, E. (2000). Controls on the dynamics of dissolved organic matter in soils a review. Soil Science., 165: 277-304.

Kharche, V. K., Patil, S. R., Kulkarni, A. A., Patil V. S. and Katkar, R. N. (2013). Long-term Integrated Nutrient Management for Enhancing Soil Quality and Crop Productivity under Intensive Cropping System on Vertisols. Journal of the Indian Society of Soil Science, 61(4) : 323-332.

Kumari, G., Mishra, B., Kumar, R., Agarawal, B.K., and Singh, B.P. (2011) Long-term effect of manure, fertilizer and lime application on active and passive pools of soil organic carbon under maize-wheat cropping system in Alfisol. Journal of the Indian Society of Soil Science, 59 (3): 245-250.

Lal, R. (2002). The potential of soils of the tropics to sequester carbon and mitigate the greenhouse effect. Adv. Agron. 76: 23-28.

McGill, W.B., Cannon, K.B., Robertson, J.A. and Cook, F.D. (1986) Dynamics of soil microbial biomass and water soluble organic carbon in Breton $\mathrm{L}$ after 50 years of cropping two rotations. Can. J. Soil Sci. 66, 1-9.

Patil, P. and Kumar, A.K. (2017). Biological carbon sequestration through fruit crops (Perennial crops-natural "Sponges"for absorbing carbon dioxide from atmosphere) Plant Archives. 17(2):1041-1046.

Pichhode, M. and Kumar, Nikhil (2017). Carbon sequestration by fruit trees species at Malanjkhand, district Balaghat , Madhya Pradesh, India, American Journal of Engineering Reaserch , 6: 6-13.

Rudrappa, L., Purakayastha, T.J., Singh, D. and Bhadraray (2006) Long-term manuring and fertilization effect on soil organic carbon pools in typic Halustept of semi-arid sub-tropical India. Soil Tillage Res. 88 : 180-192.

Singh, K., Bansal, S.K and Moinuddin (2007) Effect of continuous cropping for twenty two years on some properties of the intensively cultivated allucial soil and nutrient indexing of rice. Journal of the Indian Society of Soil Science, 55: 265-269.

Subhash Babu, Yadav G. S., Nagachan S.V.(2018). Carbon sequestration in organic farming. ICAR Research Complex for NEH Region Umiam Meghalaya.

Technical manual USETA 2001). Methods for collection, storage and manipulation of sediments for chemical and 
toxicological Analysis: Technical manual U.S. Environmental Protection Agency Washington. D.C. 204-260.

Tiessen H. and J. O. Moir (1993). Total and organic carbon In: Soil Sampling and Methods of Analysis, M. ECarter, Ed. Lewis Publishers, Ann Arbor, MI.p.187-211.

Wang, X., Jia, Y., Li, X., Long, R., Ma, Q., Li, F., Song, Y., (2009) Effects of land use on soil total and light fraction organic, and microbial biomass $\mathrm{C}$ and $\mathrm{N}$ in a semi-arid ecosystem of northwest
China. Geoderma. 153, 285-290.

Weil, R.R., Islam, K.R., Stine, M.A., Gruver, J.B., Susan, E., Liebig Samson (2003). Estimating active carbon for soil quality assessment: a simplified method for laboratory and field use. Am. J. of Alter Agric., 18 3-17.

West, T.O., Post, W.M., 2002. Soil organic carbon sequestration rates by tillage and crop rotation: a global data analysis. Soil Sci. Soc. Am. J. 66 (6), 1930-1946.

\section{How to cite this article:}

Zade, S. P., S. L. Bhosale and Gourkhede, P. H. 2020. Carbon Status in Major Fruit Orchard Soils of Parbhani District of Maharashtra, India. Int.J.Curr.Microbiol.App.Sci. 9(03): 19691979. doi: https://doi.org/10.20546/ijcmas.2020.903.229 